\title{
INCIDENCE AND PREVALENCE OF CROHN'S DISEASE AND ULERATIVE COLITIS (2013-2017) BASED ON THE LATVIAN NATIONWIDE MEDICINES REIMBURSEMENT DATABASE
}

\author{
Irēna Mirzajanova ${ }^{1, \#}$, Santa Purviṇa ${ }^{1}$, and Juris Pokrotnieks ${ }^{1,2}$ \\ ${ }^{1}$ Faculty of Pharmacy, Rīga Stradinš University, 13 Pilsoṇu Str., Rīga, LV-1002, LATVIA \\ 2 Pauls Stradiṇš Clinical University Hospital, 13 Pilsoṇu Str., Rīga, LV-1002, LATVIA \\ \# Corresponding author: irena.mirzajanova@rsu.lv
}

Communicated by Dainis Krieviṇš

\begin{abstract}
Inflammatory bowel disease (IBD) is a chronic, relapsing-remitting, inflammatory condition of the gastrointestinal tract which consists of Crohn's disease (CD), ulcerative colitis (UC) and undifferentiated IBD. Epidemiology of IBD is changing worldwide, but a significant gap remains in the description of the IBD population in Latvia. The aim of the study was to determine the incidence and prevalence rates of IBD in Latvia in the period between 2013 and 2017. Retrospective analysis of reimbursed medicines claims for IBD diagnoses from the Latvian National Health Service database (NHS) was conducted for the period of 2012 to 2017. From CD patients, 53.7\% were female and the area of residency strongly favoured urban areas vs rural districts of Latvia, $59.1 \%$ vs $40.9 \%$, respectively. A similar demographic pattern was observed in UC patients, where $56.2 \%$ were female and $55.1 \%$ of the total UC population lived in urban areas. The overall age- and sex-adjusted incidence rates for $C D$ and UC were 16.45 (CI95\% [14.68, 18.21]) and 70.53 (C/95\% [66.88, 74.19]) per 100000 population, respectively, for the entire 2013-2017 period. The prevalence of CD and UC in 2012 was 12.4 and 54.8 cases per 100000 persons, respectively, compared to 15.5 and 79.5 cases per 100000 persons in CD and UC in 2017, resulting in a 25\% increase in prevalence of $C D$ and $41 \%$ increase in UC over the 5-year period. For the first time temporal trends in IBD incidence and prevalence as well as differences across age groups and gender over a five-year period are reported for Latvia.
\end{abstract}

Key words: Crohn's disease, epidemiology, National Health Services and Central Statistics Bureau databases, incidence, prevalence.

\section{INTRODUCTION}

Inflammatory bowel disease (IBD) is a chronic, relapsingremitting, inflammatory condition of the gastrointestinal tract. It includes Crohn's disease (CD), ulcerative colitis (UC) and undifferentiated IBD (IBDU) (Ananthakrishnan, 2013). IBDU is diagnosed when the disease has features of both UC and CD (Geboes et al., 2008). The aetiology of these illnesses remains unclear; however, evidence suggests a synergic effect of genetic, environmental and health-related factors (Mahid et al., 2006; Baumgart et al., 2011; Ruel et al., 2014; Van Limbergen et al., 2014).

IBD affects both genders at similar rates, with incidence peaking in younger adults (Molodecky et al., 2012). Pa- tients with IBD usually require life-long monitoring and therapy, which significantly impacts their quality of life and has considerable implications for the health system. IBD rates in regions with previously high incidence rates have been reported to be slightly decreasing or stabilising (Leddin et at., 2014).

Incidence and prevalence of IBD is increasing worldwide with Western countries having the highest reported prevalence compared to Asian countries. However, a rapid increase in prevalence of IBD in Asia has been observed in the last years (Burisch et al., 2014).

The incidence of IBD in Latvia remains unclear and lack of data was previously highlighted in a previous study (Krus- 
tiņš and Pokrotnieks, 2014). Epidemiology of IBD is changing worldwide, but a significant gap remains in the description of the IBD population in Latvia. The aim of this study was to determine the incidence of IBD in Latvia between the years 2013 and 2017.

\section{METHODS}

In Latvia, patients have access to state reimbursed medicines for IBD if they have a documented diagnosis. The Latvian National Health Services (NHS) maintain a database of reimbursed medicines and manipulations, including consumption and utilisation data. The population of Latvia continued to decrease from 2023825 in 2013 to 1950116 in 2017 (Anonymous, 2019). The start date of 1 January 2012 for analysis was chosen as this was the time of digitalisation of reimbursed prescription medicines tracking. The study population included newly diagnosed patients with CD and UC in the study period of 2013-2017. The year 2012 data was used to distinguish between prevalence and incidence of CD and UC. The NHS database of reimbursed medicines includes information on patient sex, age, area of habitation, date of prescription, date of dispensing the medicine, name of dispensed medicine (including information on dosage form and dispensed quantity), as well as prescribing medical speciality. According to Latvian legislation on prescription of reimbursed medicines, prescription can be prescribed to cover a three-month therapy course, and a prescription as such is valid for 90 days (Anonymous, 2005). In addition, the database contains information about each physician's visit, medical procedure, hospitalisation, medication dispensed in the outpatient setting, date of service/prescription, number of days of medication supplied, and tests performed. The initial study population included all patients who were registered in NHS database as having received reimbursed prescription medicine for diagnosis of Crohn's disease and Ulcerative colitis for the period from 1 January 2012 till 30 November 2018. Data for 2018 were not included in incidence and prevalence analysis since whole year data was not available at the time of request.

In this study, patients were defined as having IBD if they received therapy for IBD at least twice with at least a 30day interval. Diagnoses were identified using appropriate ICD codes for UC (ICD-9 556; ICD-10 K51) and CD (ICD-9 555; ICD-10 K50), through which patients were further classified as CD, UC or unclassified IBD patients. The date of IBD diagnosis was considered the date of first prescription by physician. The annual incidence rates for UC and $C D$ for each gender were estimated as the number of incident patients divided by number of inhabitants in the same calendar year. Information of the size of population for each year was obtained from the Central Statistics Bureau database of Latvia (Anonymous, 2019). Some patients were registered with both $\mathrm{UC}$ and $\mathrm{CD}$, and in order to compare changes in the incidence rates over time, patients with both diagnoses were included under the first disease registered. The incidence rates were directly standardised to the 2013 Latvian population using 10-year age groups and by using the 2013 European Standard population. The 95\% confidence intervals $(\mathrm{CI})$ of the estimated incidence rates were based on a Gamma distribution (Tiwari et al., 2006). Furthermore, the mean incidence rates for $\mathrm{UC}$ and $\mathrm{CD}$ were given within different age groups $(<10,10-19,20-29$, 30-39, 40-49, 50-59, 60--69, 70-79 and > 80), and according to gender.

Poisson regression was used to estimate effect of calendar year on the incidence of $\mathrm{CD}, \mathrm{UC}$ and IBD for each sex by age groups and overall. Demographic characteristics included age, sex and area of residency (rural or urban). Patients were stratified according to the place of registration - urban (including people living in capital and eight regional size cities - Rīga, Daugavpils, Jēkabpils, Jelgava, Jūrmala, Liepāja, Rēzekne, Valmiera, Ventspils) and rural (rest). The analysis was conducted using MS Excel 2018 and SPSS version 23.0.

This study was approved by the Independent Research Ethics Committee of Rīga Stradiňš University, Rìga, Latvia, and was in compliance with Helsinki Declaration. Requested data were reviewed and approved by the NHS.

\section{RESULTS}

For the studied period of almost seven years (1 January 2012 till 30 November 2018), 4828 unique patients including paediatric were treated with reimbursed medications for CD and UC indications. From 4828 unique patients, 1311 patient received reimbursed medicine only once (Fig. 1). From those patients with only one prescription, there were 312 patients with diagnosis CD (306 adults), and with 999 patients with UC (985 adults) (Tables 1-3).

After removal of patients that received their prescription in 2011 and procured it in 2012, the number of unique patients fitting the criteria was 3089 , from which $18.6 \%$ were CD and $81.4 \%$ were UC. From CD patients, $53.7 \%$ were female and the area of residency strongly favoured urban areas vs rural districts of Latvia, 59.1 vs $40.9 \%$, respectively. A similar demographic pattern was observed in UC patients, where $56.2 \%$ were female and $55.1 \%$ of total UC population lived in urban areas (Table 4). The age of diagnosis of UC and CD differed significantly depending on sex, with the highest incidence rate in female $C D$ patients peaking twice (in 20-39 and 60-69 age groups); for male CD patients the incidence peaked in 20-39 year age subgroup. For female UC patients the incidence was evenly distributed between 20-29 up to 40-49 age subgroups, and peaked in the 70-79 age subgroup, for male patients the UC incidence peaked in the 30-39 age group (Table 5).

The directly age-standardised rates of CD and UC allowed for comparisons across years with adjustment for age distribution over time and were calculated for both $\mathrm{CD}$ and UC (Table 6). The overall age- and sex-adjusted incidence rates for $\mathrm{CD}$ and UC were 16.45 (CI95\% [14.68, 18.21]) and 70.53 (CI95\% [66.88, 74.19]) per 100000 population, re- 


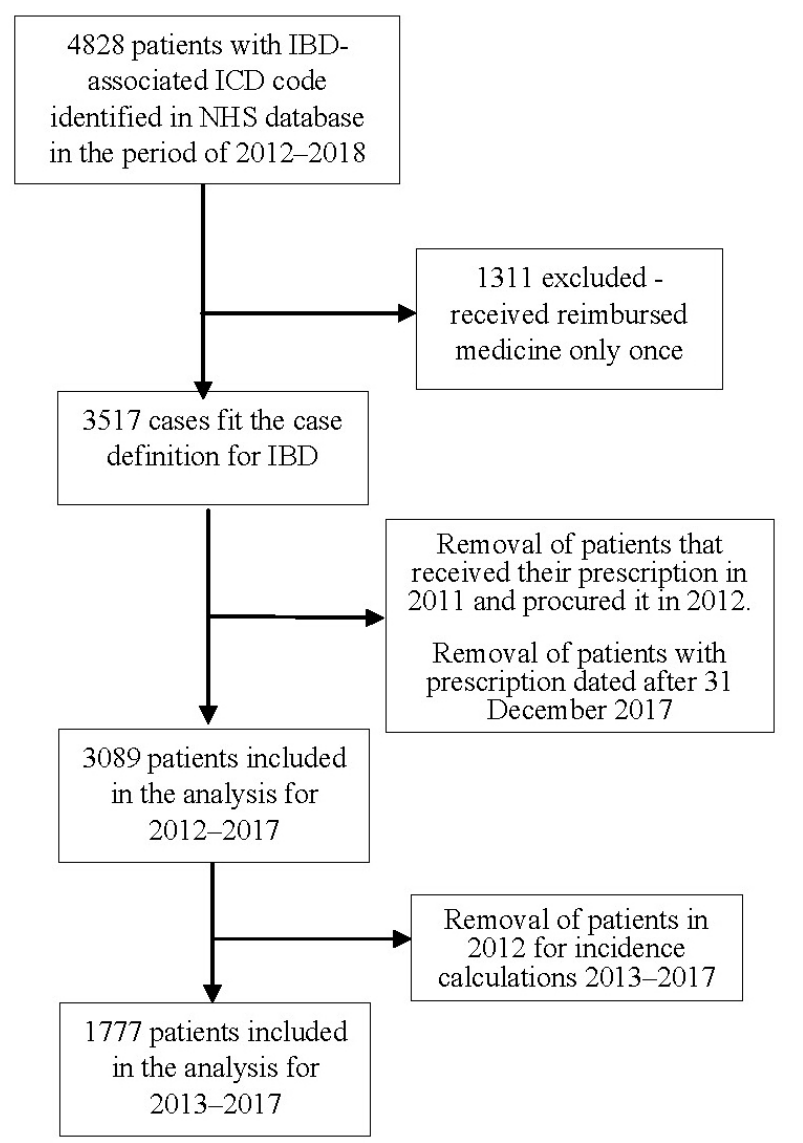

Fig. 1. Flowchart of ascertainment of inflammatory bowel disease (IBD) cases in Latvia from 2012 to 2017 CD, Crohn's disease; UC, ulcerative colitis.

Table 1. Diagnosis distribution of patients with only 1 prescription for inflammatory bowel disease diagnosis in the period of 2012-2018. Overview of patient demographic parameters

\begin{tabular}{c|c|c|c|c|c|c}
\hline Diagnosis & 2012 & 2013 & 2014 & 2015 & 2016 & 2017 \\
\hline K50 & 62 & 47 & 46 & 53 & 38 & 32 \\
K51 & 136 & 107 & 106 & 113 & 143 & 146 \\
Total & 198 & 154 & 152 & 166 & 161 & 178
\end{tabular}

Table 2. Diagnosis distribution of patients with only 1 prescription for inflammatory bowel disease diagnosis in the period of 2012-2018

\begin{tabular}{c|c|c}
\hline Diagnosis & Frequency, $\mathrm{n}$ & $\%$ \\
\hline K50.0 & 187 & 14.3 \\
K50.1 & 50 & 3.8 \\
K50.8 & 24 & 1.8 \\
K50.9 & 51 & 3.9 \\
K51.0 & 407 & 31.0 \\
K51.1 & 10 & 0.8 \\
K51.2 & 136 & 10.4 \\
K51.3 & 56 & 4.3 \\
K51.4 & 47 & 3.6 \\
K51.5 & 14 & 1.1 \\
K51.8 & 96 & 7.3 \\
K51.9 & 233 & 17.8 \\
Total & 1311 & 100.0
\end{tabular}

Table 3. Gender and area of habitation distribution of patients with only 1 prescription for inflammatory bowel disease diagnosis in the period of 2012-2018

\begin{tabular}{l|c|c|c}
\hline \multicolumn{1}{c|}{ Patient gender } & $\begin{array}{c}\text { Frequency, } \\
\text { n (\%) }\end{array}$ & $\begin{array}{c}\text { Area } \\
\text { of habitation }\end{array}$ & $\begin{array}{c}\text { Frequency, } \\
\text { n (\%) }\end{array}$ \\
\hline Male & $486(37.1)$ & Rural & $751(57.3)$ \\
Female & $825(62.9)$ & Urban & $560(42.7)$
\end{tabular}

Table 4. Demographic data on patients with IBD in Latvia, 2012-2017

\begin{tabular}{ccccc}
\hline & $\begin{array}{c}\text { IBD overall } \\
\text { total } \mathrm{n}=3089)\end{array}$ & $\begin{array}{c}\mathrm{CD} \\
\text { (total } \mathrm{n}=575)\end{array}$ & $\begin{array}{c}\text { UC } \\
\text { (total } \mathrm{n}=2514)\end{array}$ \\
\hline $\begin{array}{c}\text { Gender } \\
\text { Male }\end{array}$ & & \\
Female & 1366 & 266 & 1100 \\
Mean age, years $( \pm$ SD) & 1723 & 309 & 1414 \\
Male & $45.1 \pm 18.4$ & $40.3 \pm 18.5$ & $46.3 \pm 18.1$ \\
Female & $54.0 \pm 19.3$ & $51.9 \pm 19.3$ & $54.4 \pm 19.2$ \\
Place of living & & & 1384 \\
Urban & 1724 & 340 & 1130 \\
Rural & 1365 & 235 &
\end{tabular}

IBD, inflammatory bowel disease; CD, Crohn's disease; UC, ulcerative colitis

Table 5. Total number (\%) of incident cases of CD and UC in Latvia, 2013-2017

\begin{tabular}{|c|c|c|c|c|c|}
\hline \multirow{2}{*}{$\begin{array}{l}\text { Age group } \\
\text { Women }\end{array}$} & \multicolumn{2}{|c|}{$\mathrm{CD}$} & \multicolumn{2}{|c|}{$\mathrm{UC}$} & \multirow[t]{2}{*}{ Total } \\
\hline & $\mathrm{n}$ & $\%$ & $\mathrm{n}$ & $\%$ & \\
\hline$<10$ & 1 & 0.6 & 3 & 0.4 & 4 \\
\hline $10-19$ & 5 & 2.8 & 35 & 4.4 & 40 \\
\hline $20-29$ & 28 & 15.8 & 90 & 11.4 & 118 \\
\hline $30-39$ & 29 & 16.4 & 104 & 13.2 & 133 \\
\hline $40-49$ & 19 & 10.7 & 97 & 12.3 & 116 \\
\hline $50-59$ & 22 & 12.4 & 119 & 15.1 & 141 \\
\hline $60-69$ & 35 & 19.8 & 123 & 15.6 & 158 \\
\hline $70-79$ & 28 & 15.8 & 156 & 19.7 & 184 \\
\hline$>80$ & 10 & 5.6 & 63 & 8.0 & 73 \\
\hline All women & 177 & 100 & 790 & 100.0 & 967 \\
\hline Age group & & & & & Total \\
\hline Men & $\mathrm{N}$ & $\%$ & $\mathrm{~N}$ & $\%$ & \\
\hline$<10$ & 2 & 1.3 & 5 & 0.8 & 8 \\
\hline $10-19$ & 18 & 11.3 & 32 & 4.9 & 81 \\
\hline $20-29$ & 32 & 20.0 & 96 & 14.8 & 271 \\
\hline $30-39$ & 37 & 23.1 & 148 & 22.8 & 337 \\
\hline $40-49$ & 21 & 13.1 & 107 & 16.5 & 250 \\
\hline $50-59$ & 22 & 13.8 & 93 & 14.3 & 214 \\
\hline $60-69$ & 13 & 8.1 & 91 & 14.0 & 196 \\
\hline 70-79 & 11 & 6.9 & 63 & 9.7 & 162 \\
\hline$>80$ & 4 & 2.5 & 15 & 2.3 & 35 \\
\hline All men & 160 & 100 & 650 & 100.0 & 810 \\
\hline
\end{tabular}

$\mathrm{CD}$, Crohn's disease; UC, ulcerative colitis 
Table 6. Annual directly age-sex standardised incidence rates per 100000 patients with CD and UC in Latvia in $2013-2017$

\begin{tabular}{|c|c|c|c|c|c|c|}
\hline \multicolumn{7}{|l|}{ Crohn's disease } \\
\hline Year & Male & $\begin{array}{l}95 \% \text { CI } \\
{[\mathrm{LL}, \mathrm{UL}]}\end{array}$ & Female & $\begin{array}{l}95 \% \text { CI } \\
{[\mathrm{LL}, \mathrm{UL}]}\end{array}$ & Total & $95 \%$ CI [LL, UL] \\
\hline 2013 & 4.18 & $2.87,5.49$ & 3.37 & $2.18,4.3$ & 3.71 & $2.87,4.55$ \\
\hline 2014 & 3.71 & $2.37,5.05$ & 3.04 & $2.04,4.04$ & 3.38 & $2.54,4.21$ \\
\hline 2015 & 3.09 & $1.92,4.26$ & 3.97 & $2.8,5.14$ & 3.53 & $2.71,4,35$ \\
\hline 2016 & 2.51 & $1.52,3.51$ & 3.11 & $2.08,4.13$ & 2.81 & $2.1,3.52$ \\
\hline 2017 & 3.6 & $2.36,4.85$ & 2.13 & $1.25,3.01$ & 2.87 & $2.11,3.63$ \\
\hline \multicolumn{7}{|c|}{ Ulcerative colitis } \\
\hline Year & Male & $\begin{array}{l}95 \% \mathrm{CI} \\
{[\mathrm{LL}, \mathrm{UL}]}\end{array}$ & Female & $\begin{array}{l}95 \% \mathrm{CI} \\
{[\mathrm{LL}, \mathrm{UL}]}\end{array}$ & Total & $\begin{array}{l}95 \% \text { CI } \\
{[\mathrm{LL}, \mathrm{UL}]}\end{array}$ \\
\hline 2013 & 14.28 & $11.82,16.75$ & 14.15 & $11.96,16.34$ & 14.22 & $12.57,15.86$ \\
\hline 2014 & 13.22 & $10.81,15.63$ & 12.66 & $10.6,14.72$ & 12.94 & $11.35,14.52$ \\
\hline 2015 & 13.62 & $10.89,15.63$ & 17.05 & $14.63,19.47$ & 15.16 & $13.46,16.85$ \\
\hline 2016 & 15.84 & $13.19,18.49$ & 11.77 & $9.76,13.77$ & 13.8 & $12.14,15.47$ \\
\hline 2017 & 14.82 & $12.14,17.5$ & 12.93 & $10.82,15.03$ & 13.87 & $12.17,15.58$ \\
\hline
\end{tabular}

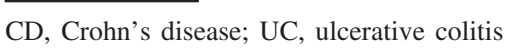

Table 7. Prevalence data by year 2012-2017 for IBD, UC and CD in Latvia

\begin{tabular}{|c|c|c|c|c|c|c|c|}
\hline Year & $\begin{array}{c}\text { Total population } \\
\text { of Latvia }\end{array}$ & $\begin{array}{c}\text { Total population } \\
\text { with IBD, } \mathrm{n}\end{array}$ & $\begin{array}{c}\text { IBD prevalence } \\
\text { per } 100000\end{array}$ & $\begin{array}{c}\text { Total population } \\
\text { with CD, n }\end{array}$ & $\begin{array}{c}\text { CD prevalence } \\
\text { per } 100000\end{array}$ & $\begin{array}{c}\text { Total population } \\
\text { with UC, } \mathrm{n}\end{array}$ & $\begin{array}{c}\text { UC prevalence } \\
\text { per } 100000\end{array}$ \\
\hline 2012 & 2044813 & 1374 & 67.2 & 253 & 12.4 & 1121 & 54.8 \\
\hline 2014 & 2001468 & 1516 & 75.7 & 283 & 14.1 & 1233 & 61.6 \\
\hline 2015 & 1986096 & 1661 & 83.6 & 326 & 16.4 & 1335 & 67.2 \\
\hline 2016 & 1968957 & 1775 & 90.1 & 308 & 15.6 & 1467 & 74.5 \\
\hline 2017 & 1950116 & 1852 & 95.0 & 302 & 15.5 & 1550 & 79.5 \\
\hline
\end{tabular}

IBD, inflammatory bowel disease; CD, Crohn's disease; UC, ulcerative colitis

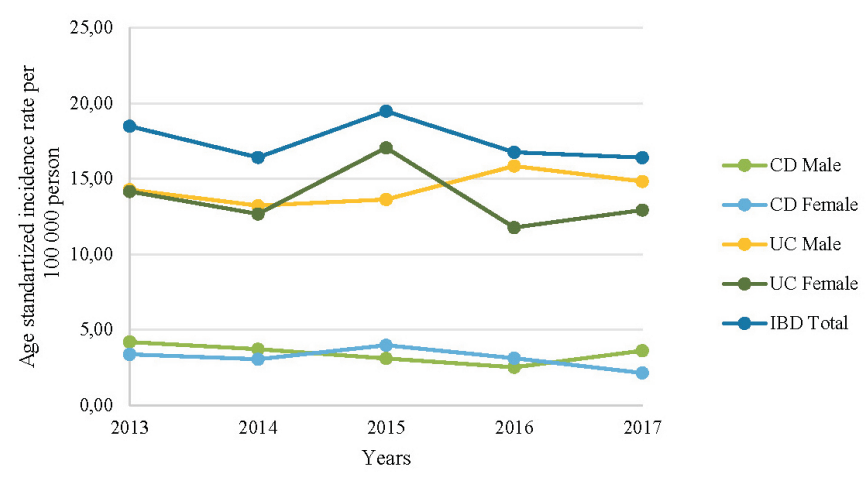

Fig. 2. Directly age-standardised incidence rates of Crohn's disease (CD), ulcerative colitis (UC) and inflammatory bowel disease (IBD) in Latvia, 2013-2017.

spectively, for the entire 2013-2017 period (Fig. 2). Ageand sex-adjusted incidence rates for CD decreased during the study period from 2013 to 2017. Poisson regression analysis showed that female sex was significantly associated with higher incidence rate of CD $(p<0.001)$, whereas area of habitation was not. Similar results were observed in UC patients with female sex being significantly associated with higher incidence rate of UC $(p<0.001)$.

The age- and sex-adjusted prevalence for $\mathrm{CD}$ and UC was calculated (Table 7). The prevalence of CD and UC in 2012

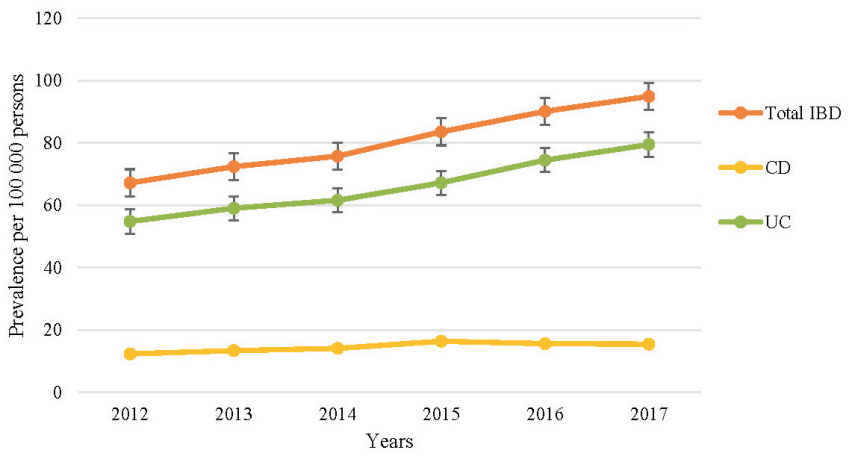

Fig. 3. Prevalence of IBD, UC and CD in Latvia in the period from 2012 to 2017.

was 12.4 and 54.8 cases per 100000 persons, respectively, compared to 15.5 and 79.5 cases per 100000 persons in CD and UC in 2017, resulting in a $25 \%$ increase in prevalence of CD and $41 \%$ increase in UC (Fig. 3).

\section{DISCUSSION}

This study of descriptive epidemiology of CD and UC in a population-based cohort of Latvian patients between 2013 and 2017 showed a decrease in the incidence rate but increase in prevalence. The increasing prevalence of $\mathrm{CD}$ and 
UC may be due to the fact that patients are living longer with the disease and that the disease itself is better managed, leading to normal or near-normal life expectancy. Such a phenomenon is described in the literature as "compounding prevalence" (Kaplan, 2015). Incidence and prevalence of CD and UC have been extensively studied in various countries (Kiudelis et al., 2012; Agnarsson et al., 2013; Leddin et al., 2014; Lucendo et al., 2014; Nørgård et al., 2014; Kim et al., 2015). Compared to other countries, incidence of $\mathrm{CD}$ in Latvia is similar to that in countries with lower incidence, whereas for UC incidence is similar to that in Scandinavian countries (Lophaven et al., 2017). Absolute prevalence of IBD, UC and CD seems relatively low $(0.095 \%, 0.015 \%$ and $0.08 \%$, respectively) but increasing through the five-year period, which is in consensus with global trends where the age-standardised prevalence rate increased from 79.5 (75.9-83.5) per 100000 population in 1990 to $84.3(79.2-89.9)$ per 100000 population in 2017 (Alatab et al., 2020). Recent prevalence estimates from Scandinavia, Western Europe and North America range from $0.21 \%$ to $0.44 \%$ for IBD, from $0.007 \%$ to $0.27 \%$ for Crohn's disease (CD) and from $0.008 \%$ to $0.29 \%$ for ulcerative colitis (Green et al., 2006; Juillerat et al., 2008; Manninen et al., 2010). However, a direct comparison of these estimates is complicated by differences in data sources and collection techniques, case ascertainment, diagnostic criteria used, study period and limited sample sizes.

Compared to other studies, the Latvian population seems to have later onset of UC and CD independently of sex, which might be explained by longer time till diagnosis, and epidemiologically is reflected as a shift towards a more adult population.

Study limitations include the case identification algorithm, since it was not validated previously in the Latvian patient cohort. It might be that having two prescriptions with at least a 30-day interval is not sufficient to distinguish a true IBD patient from a patient with IBD-like symptoms. Additionally, diagnosis could not be verified, as by endoscopies or radiological investigation that are deemed necessary to prove the diagnosis of IBD. Therefore, overestimation of the true IBD population in Latvia is possible.

Our study has several strengths. First and foremost, the data derive from a large, well-defined population with nationwide coverage. The use of nationwide data of all Latvian residents makes observations obtained in this retrospective study independent of regional differences in practice patterns, exposures, and genetic susceptibility. For the first time we have investigated temporal trends in IBD incidence as well as differences across age groups and gender over a five-year period, and studies covering a longer time period could complement the existing evidence and provide a comprehensive long-term picture of IBD in Latvia.

An important consideration when examining the data was the peak in age-standardised incidence rates in 2015, which can be explained by a change of medication reimbursement policy. Before 2015, medications for IBD were reimbursed by the state in the amount of 50 or $75 \%$, whereas starting from 2015 some important groups of medications were $100 \%$ reimbursed; this year was also highlighted by broader accessibility to biologic therapy (Anonymous, 2015). The peak might be attributed to changes in the reimbursement conditions, which shifted part of the patients that were previously paying for the therapy out-of-pocket to the reimbursed service sector.

Another important finding was the number of unique patients with IBD diagnosis that were lost on follow up or could be probably misdiagnosed, with the trend to increase over time. This highlights the need for more thorough patient monitoring and usage of other diagnoses, e.g. K52 (unspecified colitis), before a robust IBD diagnosis is made.

\section{CONCLUSIONS}

In conclusion, we report that the prevalence of UC and CD is increasing based on data from medically treated IBD patients. The evidence from this study indicates that incidence rates of both $\mathrm{CD}$ and UC are declining. This study highlights a large and progressively growing population of IBD patients who will require further study. Additional studies in the Latvian and Baltic populations are needed with more stringent validation and inclusion criteria, as well as prospective IBD registries. This has implications for both epidemiology and health planning.

\section{REFERENCES}

Agnarsson, U., Björnsson, S., Jóhansson, J. H., Sigurdsson, L.(2013). Inflammatory bowel disease in Icelandic children 1951-2010. Population-based study involving one nation over six decades. Scand. J. Gastroenter., 48, 1399-1404.

Alatab, S., Sepanlou, S. G., Ikuta, K., Vahedi, H., Bisignano, C., Safiri, S., Sadeghi, A., Nixon, M. R., Abdoli, A., Abolhassani, H., Alipour, V. (2020). The global, regional, and national burden of inflammatory bowel disease in 195 countries and territories, 1990-2017: A systematic analysis for the Global Burden of Disease Study 2017. Lancet Gastroenter. Hepatol., 5 (1), 17-30.

Ananthakrishnan, A. N. (2015). Epidemiology and risk factors for IBD. Nature Rev. Gastroenterol. Hepatol., 12 (4), 205.

Anonymous (2005). Republic of Latvia Cabinet Regulation No. 175, adopted 8 March 2005. Regulations Regarding Manufacture and Storage of Prescription Forms, as well as Writing out and Storage of Prescriptions. https://likumi.lv/ta/id/104228 (accessed 30 December 2019).

Anonymous (2015). System of Normative Acts. http://ligumi.vmnvd.gov.lv/nas/library.nsf (accessed 19 December 2019).

Anonymous (2019). Population of Latvia by citizenship and sex at the beginning of the year (by 5-years age groups). Central Statistics Bureau database. https://www.csb.gov.lv/en/statistics/statistics-by-theme/population/characteristics/tables/irg 120/population-latvia-citizenship-and-sex-b eginning (accessed 29 December 2019).

Baumgart, D. C., Bernstein, C. N., Abbas, Z., Colombel, J. F., Day, A. S., D'Haens, G., Dotan, I., Goh, K. L., Hibi, T., Kozarek, R. A., Quigley, E. M., Reinisch, W., Sands, B. E., Sollano, J. D., Steinhart, A. H., Steinwurz, F., Vatn, M. H., Yamamoto-Furusho, J. K. (2011). IBD Around the world: Comparing the epidemiology, diagnosis, and treatment. Proceedings of the World Digestive Health Day 2010-Inflammatory Bowel Disease Task Force Meeting. Inflamm. Bowel Dis., 17 (2), 639-644. 
Burisch, J., Pedersen, N., Čuković-Čavka, S., Brinar, M., Kaimakliotis, I., Duricova, D., Shonova, O., Vind, I., Avnstrom, S., Thorsgaard, N. et al. (2014). East-West gradient in the incidence of inflammatory bowel disease in Europe: The ECCO-Epi- Com inception cohort. Gut, 63, 588-597.

Geboes, K., Colombel, J. F., Greenstein, A., Jewell, D. P., Sandborn, W. J., Vatn, M. H., Warren, B., Riddell, R. H. (2008). Indeterminate colitis: A review of the concept-what's in a name? Inflamm. Bowel Dis., 14 (6), $850-857$.

Green, C., Elliott, L., Beaudoin, C., Bernstein, C. N. (2006). A population-based ecologic study of inflammatory bowel disease: Searching for etiologic clues. Amer. J. Epidemiol., 164, 615-623.

Juillerat, P., Pittet, V., Bulliard, J. L., Guessous, I., Antonino, A. T., Mottet, C., Felley, C., Vader, J.-P., Michetti, P. (2008). Prevalence of inflammatory bowel disease in the Canton of Vaud (Switzerland): A population-based cohort study. J. Crohns Colitis, 2, 131-141.

Kaplan, G. G. (2015). The global burden of IBD: From 2015 to 2025. Nature Rev. Gastroenterol. Hepatol., 12,720-727.

Kim, H. J., Hann, H. J., Hong, S. N., Kim, H. K., Ahn, I. M., Song, Y. Y., Lee, S. H., Ahn, H. S. (2015). Incidence and natural course of inflammatory bowel disease in Korea, 2006-2012: A nationwide population-based study. Inflamm. Bowel Dis., 21, 623-630.

Kiudelis, G., Jonaitis, L., Adamonis, K., Žvirblienè, A., Tamelis, A., Kregždytė, R., Kučinskienė, R., Šventoraitytė, J., Kupčinskas, L. (2012). Incidence of inflammatory bowel disease in Kaunas region, Lithuania. Medicina, 48 (8), 64

Krustins, E., Pokrotnieks, J. (2014). IBD prevalence in Baltic states or just a guessing game? J. Crohn's Colitis, 8 (8), 902-902.

Leddin, D., Tamim, H., Levy, A. R. (2014). Decreasing incidence of inflammatory bowel disease in eastern Canada: A population database study. BMC Gastroenterol., 14 (1), 140.
Lophaven, S. N., Lynge, E., Burisch, J. (2017). The incidence of inflammatory bowel disease in Denmark 1980-2013: A nationwide cohort study. Alimentary Pharmac. Ther., 45 (7), 961-972.

Lucendo, A. J., Hervías, D., Roncero, Ó., Lorente, R., Bouhmidi, A., Angueira, T., Verdejo, C., Saluena, I., Gonzalez-Castillo, S., Arias, A. (2014). Epidemiology and temporal trends (2000-2012) of inflammatory bowel disease in adult patients in a central region of Spain. Eur. J. Gastroenterol. Hepatol., 26, 1399-1407.

Mahid, S. S., Minor, K. S., Soto, R. E., Hornung, C. A., Galandiuk, S. (2006). Smoking and inflammatory bowel disease: A meta-analysis. Mayo Clin. Proc., 81, 1462-1471.

Manninen, P., Karvonen, A. L., Huhtala, H., Rasmussen, M., Collin, P. (2010). The epidemiology of inflammatory bowel diseases in Finland. Scand. J. Gastroenterol., 45, 1063-1067.

Molodecky, N. A., Soon, I. S., Rabi, D. M., Ghali, W. A., Ferris, M., Chernoff, G., Benchimol, E. I., Panaccione, R., Ghosh, S., Barkema, H. W. Kaplan, G. G. (2012). Increasing incidence and prevalence of the inflammatory bowel diseases with time, based on systematic review. Gastroenterology, 142, 46-54; e42; quiz e30.

Nørgård, B. M., Nielsen, J., Fonager, K., Kjeldsen, J., Jacobsen, B. A., Qvist, N. (2014). The incidence of ulcerative colitis (1995-2011) and Crohn's disease (1995-2012), based on nationwide Danish registry data. J. Crohn's Colitis, 8 (10), 1274-1280.

Ruel, J., Ruane, D., Mehandru, S., Gower-Rousseau, C., Colombel, J. F. (2014). IBD across the age spectrum: Is it the same disease? Nat. Rev. Gastroenterol. Hepatol., 11, 88-98.

Tiwari, R. C., Clegg, L. X., Zou, Z. (2006). Efficient interval estimation for age-adjusted cancer rates. Stat. Methods Med. Res., 15, 547-569.

Van Limbergen, J., Radford-Smith, G., Satsangi, J. (2014). Advances in IBD genetics. Nat. Rev. Gastroenterol. Hepatol., 11, 372-385.

\section{KRONA SLIMĪBAS UN ČŪLAINĀ KOLĪTA INCIDENCE UN PREVALENCE 2013.-2017.GADĀ, BALSTOTIES UZ LATVIJAS NACIONĀLO KOMPENSĒJAMO MEDIKAMENTU DATUBĀZI}

Iekaisīgā zarnu slimība (IZS) ir hronisks, recidivējoši remitējošs kuṇǵa-zarnu trakta iekaisuma stāvoklis, kas iekḷauj tādas slimības kā Krona slimība (KS), čūlainais kolīts (ČK) un nediferencēta IZS. IZS epidemioloǵija mainās visā pasaulē, tomēr IZS populācijas raksturojums Latvijā līdz šim brīdim nav veikts. Pētîjuma mērḳis bija izpētīt IZS incidences un prevalences rādītājus Latvijā laikposmā no 2013. līdz 2017. gadam. Tika veikta Latvijas Nacionālā veselības dienesta (NVD) kompensējamo zāḷu pieprasījumu IZS diagnozei retrospektīva analīze, ietverot laika posmu no 2012. gada līdz 2017. gadam. 2017. gadā no KS pacientiem 53,7\% bija sievietes, un lielākā dala pacientu dzīvoja pilsētās, nevis lauku reǵionos, attiecīgi 59,1 pret 40,9\%. Līdzīgs demogrāfiskais modelis tika novērots ČK pacientiem, kur $56,2 \%$ bija sievietes un 55,1\% no visiem ČKK iedzīvotājiem dzīvoja pilsētās. Kopējā vecuma un dzimuma koriğêtā incidence KS un ČKK bija attiecīgi 16,45 (CI95\% [14,68; 18,21]) un 70,53 (CI95\% [66,88; 74,19]) uz 100000 iedzīvotājiem laikposmā no 2013. līdz 2017. gadam. KS un ČK prevalence 2012. gadā bija attiecīgi 12,4 un 54,8 gadījumi uz 100000 iedzīvotājiem, salīdzinot ar 15,5 un 79,5 gadījumiem uz 100000 iedzīvotājiem KS un ČK 2017. gadā, palielinot KS un ČK izplatību piecu gadu laikā attiecīgi par 25\% un 41\%. Šis ir pirmais pētījums, kurā tiek analizēti Latvijas IZS populācijas incidences un prevalences dati, kā arī atškiriribas vecuma grupās un dzimumos piecu gadu periodā. 